JURNAL ILMIAH MANAJEMEN BISNIS DAN INOVASI UNIVERSITAS SAM RATULANGI (JMBI UNSRAT)

\title{
BLACK SWAN GLOBAL MARKET: ANALYSIS OF THE EFFECT OF THE COVID-19 DEATH RATE ON THE VOLATILITY OF EUROPEAN FOOTBALL CLUB STOCK PRICES (CASE STUDY OF JUVENTUS F.C., MANCHESTER UNITED, AJAX AMSTERDAM AND BORUSSIA DORTMUND)
}

\section{Franco Benony Limba, Jacobus Cliff Diky Rijoly, Margreath I Tarangi}

Universitas Pattimura Ambon, IPDN Jakarta

\section{A R T I C L E I N F O}

\section{Keywords: Black Swan Global} Market, Covid-19 Pandemic, TGARCH Models
Kata kunci: Black Swan Global Market, Pandemi Covid-19, TGARCH Models

Corresponding author: Jacobus Cliff Diky Rijoly valdyrijoly@gmail.com
Abstract: The Covid-19 pandemic that hit the world also directly affected financial markets and global stock markets; this condition in economic terminology is known as the Black Swann Global Market Effect. Black Swan Global Market Effect is also experienced by sports industries in the financial industry, the football industry. The purpose of this paper is to see whether there is an influence between the Covid-19 pandemic conditions on the share value of several major European football clubs, namely Ajax Amsterdam, Borussia Dortmund, Juventus F.C., and Manchester United, as a result of the Black Swan Global Market Effect. The data used in this paper is time-series data from March 2020 to August 2020. Meanwhile, to answer the black swan effect phenomenon, the Threshold Generalized Autoregressive Conditional Heteroskedasticity (TGARCH) method is used. The results showed that stocks that were the object of research (Ajax, Borussia Dortmund, Juventus, and Machester United) showed a large response to bad News (an increase in deaths due to covid-19).

Abstrak:Pandemic covid-19 yang mengantam dunia juga secara langsung mempengaruhi pasar keuangan serta pasar saham global, kondisi ini dalam terminology ekonomi dikenal sebagai Black Swann Global Markert Effect. Black Swan Global Market Effect hal ini juga dialami industry-industri olahraga yang berada dalam industry keuangan tersebut salah satunya industry sepakbola.Tujuan penulisan ini adalah untuk melihat apakah terdapat pengaruh antara kondisi pandemic covid-19 terhadap nilai saham beberapa klub sepakbola besar eropa yaitu Ajax Amsterdam, Borussia Dortmund, Juventus FC, dan Manchester United sebagai akibat dari Black Swan Global Market Effect.Data yang digunakan dalam penulisan ini adalah data time series dari bulan maret 2020 hingga agustus 2020. Sementara untuk menjawab fenomoena black swan effect ini digunakan metode Threshold Generalized Autoregressive Conditional Heteroskedacity (TGARCH). Hasil Penelitian menunjukkan bahwa, saham-saham yang menjadi objek penelitian (Ajax, Borussia Dortmund, Juventus, dan Machester United) menunjukan respons yang besar terhadap bad news (peningkatan jumlah kematian akibat covid-19). 


\section{INTRODUCTION}

The novel Coronavirus Disease, known as Covid-19 was first reported in Wuhan City, China, with a ferocious and fast spread to many countries (Xu et al., 2020). (WHO, 2020a) explains that the method of spreading the coronavirus is through people who have been infected with Covid-19. This virus can spread through tiny droplets from the nose or mouth. When infected with this virus will experience sneezes or coughs. The droplets then land on an object or surface where they are touched, and the healthy person touches their eyes, nose, or mouth. Covid-19 can also spread when the tiny droplets are inhaled by someone when they are in close contact with an infected person

Table 1. WHO Data Positive Cases and Covid-19 Death Rate

\begin{tabular}{lll}
\hline Area & $\begin{array}{l}\text { Confirmed } \\
\text { Positive }\end{array}$ & Deaths \\
\hline Global & 2.397 .217 & 162.956 \\
\hline European Region & 1.187 .184 & 106.342 \\
\hline Region of the Americas & 893.119 & 42.686 \\
\hline Western Pacific Region & 134.507 & 5.685 \\
\hline Eastern Mediterranean Region & 134.507 & 6.185 \\
\hline Southeast Asia Region & 31.670 & 1.341 \\
\hline African Region & 15.555 & 704 \\
\hline
\end{tabular}

Source: (WHO, from national authorities by 10:00 CEST, April 21, 2020)

However, since the first case of Covid-19 was announced in Europe on February 21, 2020 (Spiteri et al. 2020), the European continent has become the worst-hit region with the highest number of positive cases highest mortality rate in the world (see Table 1). Covid-19 has become a pandemic that has paralyzed many activities in other parts of the world, including European football competitions. Postponements of matches and competitions occurred after several soccer players tested positive for Covid-19. The postponement of all matches is a form of protection for soccer players and prevents rapid spread. Covid-19 is not only harmful to humans. Personally, it can cripple business entities such as the football industry.

(Gunardi 2014) explained that the European football industry had entered an era of great business. Data from the Deloitte Money League (Deloitte U.K. 2020) explains that in the 2018/2019 period, the top 20 clubs in the ranking they created generated a combined income of $€ 9.3$ billion, up $11 \%$ from the previous season. The $€ 939$ million increase in revenue was driven by broadcast revenue of $€ 575$ million (up 16\%), commercial revenue of $€ 313$ million (up 9\%), and matchday revenue of $€ 51$ million (up 4\%). This was confirmed by (Herdyastoro and Frensidy 2014), who explained that clubs carry out two complementary functions in the football industry: competition and business function. The postponement of this match resulted in the postponement of local competitions' schedule to the big European competition, namely EURO 2020. On the other hand, European football clubs also suffered losses due to the delay. The club is very dependent on matches because the source of club income comes from match tickets, the sale of match broadcasting rights, and commercial contract revenue (Haryoprasetyo and Kiswara 2013).

For example, Juventus F.C., which is involved in three tournaments, namely the Italian League, Copa Italia, and UEFA Champions League, certainly feels the impact of Covid-19 on club revenues. This match's postponement made the club management and the players and first-team coaches agree to cut wages during March - June 2020 (www.juventus.com, 2020). The club made savings of 90 Million Euros to help 
finance the club in the 2019-2020 financial period. The German League club, Borussia Dortmund (ESPN 2020), also imposed a pay cut for players to help finance the club. The health condition of the players and also the health of the club remains a priority for management. However, cutting players' wages does not apply to the Premier League club: Manchester United, who feel confident in their financial condition.

European football clubs must comply with UEFA's Financial Fair Play (FFP) rules that have been implemented since 2011. Through the FFP, which came into effect in 2011, each club is expected to increase the economic and financial capacity of a more transparent and credible club (UEFA 2018). Also, some active clubs on the stock exchange must comply with IFRS rules in presenting their financial activities fairly and maintain financial performance. Good financial performance will attract interest from investors. Before Covid-19 became a pandemic in the world, European club stock prices depended not only on financial performance but also on 11 players on the field (Setiaji 2018). Therefore, with the postponement of matches and reduced club income due to Covid-19, it will be difficult for management to maintain financial performance and keep stock price movements stable.

(Morales and Andreosso-O'Callaghan 2020) describes the spread of Covid-19 as a black swan on the global market. Lack of action and coordination from world leaders as a global effort to control Covid19 panicked global stock markets and resulted in global stock markets plummeting Monday, March 9 and Thursday, March 12, 2020. Research findings using the Granger Causality Test show that markets are not reacted to the level of Volatility shown by the Chinese stock market identified as the epicenter of the Covid19 spread. However, the stock market began to react to the threat of Covid-19 when Italy announced its first case, and it quickly took a toll on fear in Europe. Besides, a similar study was also conducted by (Onali 2020), who used the GARCH Model to explain that the reported mortality rate due to Covid-19 in America and five other countries (Italy, Spain, UK, France, and Iran) did not affect the return of the American market. However, the VAR model shows that the reported mortality rate in Italy and France harms the market return and positively impacts the VIX return on the American stock market.

The spread of Covid-19 as an extraordinary phenomenon has also impacted the European football industry as an industry with a large turnover and involving many people, lockdown policies, and postponement of competition to prevent the spread of Covid-19 in several European countries affect club income. For soccer clubs that are active in the stock market, a decrease in income can trigger the possibility of a decline in share prices. The high mortality rate due to Covid-19 sends bad news signals to investors, resulting in Volatility in stock prices, including stock prices of European football clubs.

This study captures a gap from previous research conducted by Morales and Andreosso-O'Callaghan (2020) and Onali's research (2020), which explains the effect of Covid-19 on the global market. This study aims to analyze the black swan Covid-19 phenomenon, which focuses on the effect of death reports in Europe on the Volatility of stock prices of European football clubs, namely Juventus (Italy), Manchester United (England), Borussia Dortmund (Germany), and Ajax Amsterdam (Netherlands).

\section{THEORETICAL ANALYSIS}

\section{Black Swan Theory}

Black Swan are events that happen unexpectedly and cause quite a stir in the financial markets. The term "Black Swan" originated in the 17th century, stems from the European assumption that all geese are white when there are black geese that live in the wild. In this context, the black swan (Black Swan) is often seen as a symbol for unpredictable and has a significant impact and something that is out of control.

(Taleb 2007) who popularized the term Black Swan in financial markets, explaining that Black Swan consists of three main characteristics, namely: (1) is an event that has never happened or an event that cannot be predicted, (2) has an enormous impact, (3) people rationalize the incident with simple explanations. The postponement of European football competitions due to the spread of Covid-19 was an unexpected event. 
The spread of Covid-19 has had a significant impact on the European football industry, the delays in competition, decreased income, and football clubs' stock price. The slow pace of prevention and weak awareness of the dangers of Covid-19 have made European countries the region with the highest number of positive cases and death tolls in the world.

\section{Stock Price Volatility}

Stock price volatility is the fluctuation of shares, the return of a security or portfolio within a certain period (Hartono 2010). (Habib and Khan 2012) On the other hand, stock price volatility is a systemic risk that only investors who invest in stocks face. According to (Hussainey, Oscar Mgbame, and ChijokeMgbame 2011), stock price volatility is a measure in determining risk in investment. It can show the level of change in stock prices during a specific period. Market volatility can occur due to new information into the market or, As a result; market players re-evaluate the company's assets. The market price level will make a quick adjustment so that the price formed reflects the new information or condition.

Volatility can also be used in forecasting. Forecasting activities in finance are using time series data. This sometimes causes the phenomenon of heteroscedasticity. The Volatility can be caused by market movements that suddenly plummet, and if there is bad News, it will calm down sometime later. Volatility means that the data experiences extreme fluctuation or volatility clustering (Ariefianto 2012). Volatility reflects the level of risk of an investment asset. A high level of Volatility indicates high risk and also a high rate of return. Knowing the level of Volatility of investment assets owned will make investors wiser in managing their investments. The spread of Covid-19 in Europe is spreading rapidly, and the high death toll sends terrible News to investors. This condition can generate the Volatility of stock prices, including the stock prices of European football clubs.

\section{METHODOLOGY}

This study uses data from football clubs from four European countries that are actively on the stock market, including Juventus (Italy), Manchester United (U.K.), Borussia Dortmund (Germany), Ajax Amsterdam (Netherlands). The club's stock price volatility data was obtained from Yahoo! Finance. Meanwhile, the death rate report data obtained from the WHO daily data is data on death reports in Italy, the UK, Germany, and the Netherlands, where reports of mortality rates in the European region increased. The data used covers the period from February 01 to May 01, 2020. This study uses the ARCH-GARCH (Autoregressive Conditional Heteroskedasticity-Generalized Autoregressive Conditional Heteroskedasticity) model.

The ARCH model was first introduced by (Engle, 1982), aiming to solve Varying Time-Dependent errors.

Meanwhile, the basic ARCH model developed by Engle is as follows:

$$
\begin{aligned}
& y_{t}=x_{t} \beta+\varepsilon_{t} \text { (Conditional Mean) } \ldots \ldots \ldots \ldots \ldots \ldots \ldots \ldots \ldots \ldots \ldots \ldots \\
& \sigma_{t}^{2}=\gamma_{0}+\gamma_{1} \epsilon_{t-1}^{2}+\gamma_{2} \epsilon_{t-2}^{2}+\cdots+\gamma_{p} \epsilon_{t-p}^{2}(\text { Conditional Variance }) \ldots . .2
\end{aligned}
$$

Where:

$\epsilon_{t}^{2}=$ squared residual (innovation), and

$y_{i}=\mathrm{ARCH}$ Parameter

Meanwhile, the GARCH Model is a development of the ARCH model (Bollerslev 1986); in this model, the conditional variance lagged values are added. This development assumes that GARCH tends to have consistency with observed volatility clustering in financial return data. When there is a large change 
in stock return data, it tends to be followed by further significant changes (Rijoly 2015). The Simple GARCH model can be seen in the equation below:

$$
\sigma_{t}^{2}=\gamma_{0}+\gamma_{1} \epsilon_{t-1}^{2}+\gamma_{2} \epsilon_{t-2}^{2}+\cdots+\gamma_{p} \epsilon_{t-p}^{2}+\delta_{1} \sigma_{t-1}^{2}+\delta_{2} \sigma_{t-2}^{2}+\cdots+\delta_{q} \sigma_{t-q}^{2} \cdots \cdots 3
$$

\section{Where:}

$\gamma_{i}$ is ARCH Parameter, and

$\delta_{i}$ is GARCH Parameter

The use of the GARCH model is used to measure the stochastic deviation $/ \gamma_{i}$ in the previous estimation period $\left(\sigma_{t}\right)$ and see how it affects the current variance $\left(\delta_{1}\right)$ (Sukati, 2013). Furthermore, to find out how good news and bad news affect stock volatility analysis on the object of observation, especially during the Covid-19 pandemic. So the TGARCH (Threshold GARCH) model is used as a modification to the simple GARCH model. This model was developed by (Zakoian 1994). In simple terms, this model can accommodate the Asymmetric Information in the conditional variation. Here is the TGARCH equation:

Where:

$$
\sigma_{t}^{2}=\alpha+\gamma_{1} \varepsilon_{t-1}^{2}+\partial d_{t-1} \varepsilon_{t-1}^{2}+\delta_{1} \sigma_{t-1}^{2} \ldots \ldots \ldots . .4
$$

$$
d_{t} \begin{cases}1 & \varepsilon_{t}<0 \\ 0 & \varepsilon_{t} \geq 0 \quad(\text { Bad News })\end{cases}
$$

The use of TGARCH will give better results than the GARCH model (Sabiruzzaman et al. 2010) because it can separate the impact caused by both Bad News and Good News.

\section{Data Characteristic}

\section{RESULT AND DISCUSSION}

The data used in this study are daily data on stock closures from the four stocks selected in this study; besides that, it is also adjusted for the death rate due to the Covid-19 pandemic in the same countries as the 4 stocks listed (Italy, Germany, Netherlands, and U.K.). The research period itself starts from March 2020 to August 2020, while the data characteristics of the data can be seen in the image below:
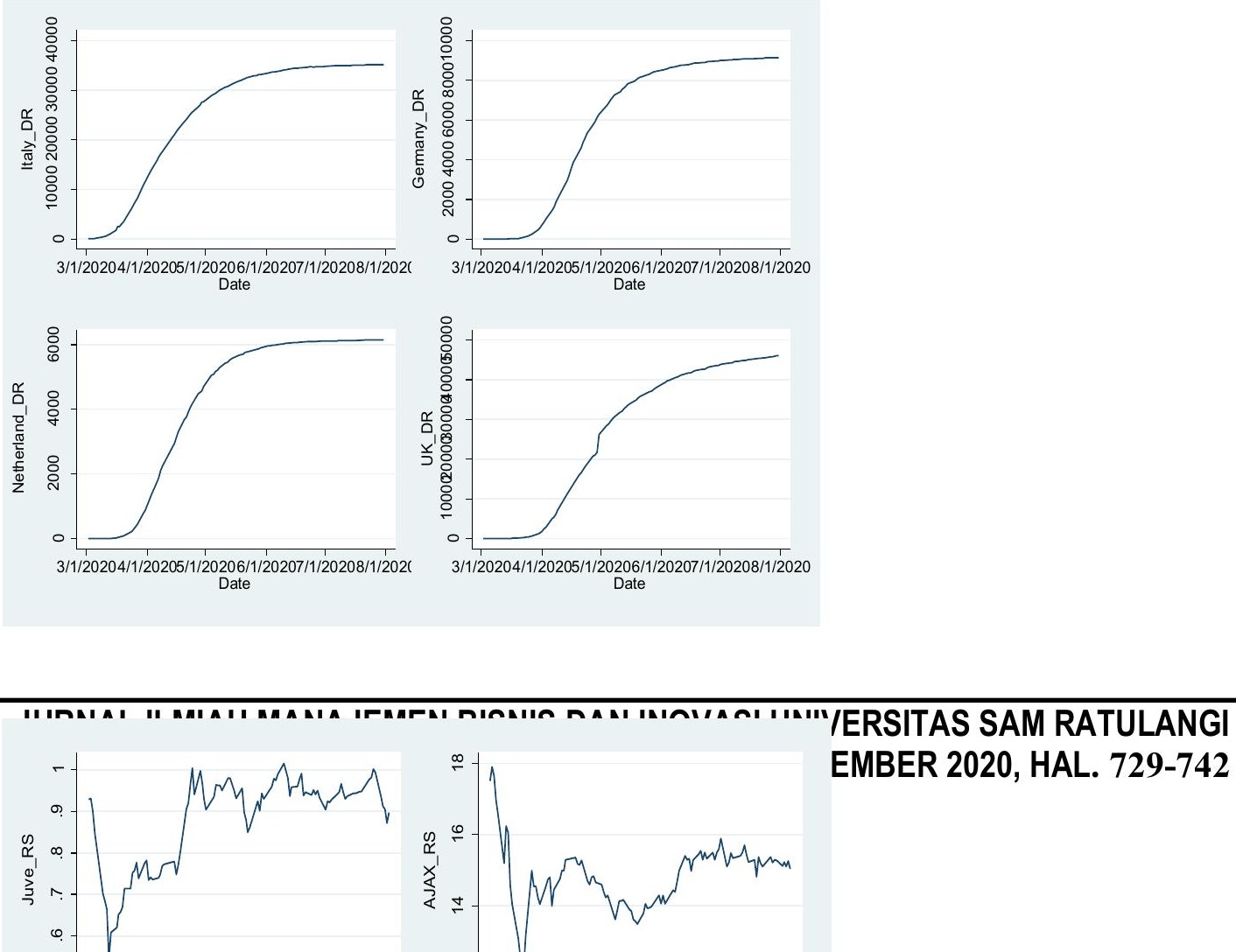
Figure 1. Juventus, Ajax, BvB, and Manchester United Shares Vs Death rate in Italy, Germany, Netherlands, and U.K

\section{Ajax Result}

Table 2.TGARCH Estimation for Ajax Amsterdam FC Shares During the Covid-19 Pandemic March-August 2020 Period Tgarch Result

Dependent Variable: AJAX

Method: ML ARCH - Normal distribution (BFGS / Marquardt steps)

Date: 09/04/20 Time: 11:56

Sample: 1103

Included observations: 103

\begin{tabular}{cccrr}
\hline \hline Variable & Coefficient & Std. Error & z-Statistic & Prob. \\
\hline \hline @SQRT(GARCH) & -1.098905 & 0.261210 & -4.206973 & 0.0000 \\
NETHERLANDS_DR & $7.80 \mathrm{E}-05$ & $2.49 \mathrm{E}-05$ & 3.128712 & 0.0018 \\
$\mathrm{C}$ & 15.07228 & 0.177038 & 85.13571 & 0.0000 \\
\hline \hline & Variance Equation & & 0.0937 \\
$\mathrm{C}$ & 0.013432 & 0.008014 & 1.676090 & 0.3215
\end{tabular}




\begin{tabular}{|c|c|c|c|c|}
\hline $\operatorname{RESID}(-1)^{\wedge} 2^{*}(\operatorname{RESID}(-1)<0)$ & 0.456803 & 0.141694 & 3.223870 & 0.0013 \\
\hline GARCH(-1) & 0.632555 & 0.100945 & 6.266315 & 0.0000 \\
\hline R-squared & -1.030193 & Mean dependent var & & 14.84874 \\
\hline Adjusted R-squared & -1.070797 & S.D. dependent var & & 0.936586 \\
\hline S.E. of regression & 1.347772 & Akaike info criterion & & 1.551242 \\
\hline Sum squared resid & 181.6490 & Schwarz criterion & & 1.730301 \\
\hline Log likelihood & -72.88895 & Hannan-Quinn criter. & & 1.623767 \\
\hline Durbin-Watson stat & 0.117870 & & & \\
\hline
\end{tabular}

Source: Author Computation (2020)

From the estimation results above on the F.C. ajax amsterdam stock during this pandemic, it shows the coefficient of the TARCH parameter (RESID $(-1)^{\wedge} 2 *($ RESID $(-1)<0)$ is 0.456803 and significant $(p$ value $=0.0013$ ) which means that the market did respond more to bad News (the emergence of a pandemic followed by an increase in the number of deaths in the Netherlands), so it directly affects the level of Volatility of Ajax Amsterdam FC stock returns.

\section{BVB Result}

Table 3. Estimated Tgarch for Borussia Dortmund F.C. Shares During the Covid-19 Pandemic March-August 2020 Period 
Source: Author Computation (2020)

Dependent Variable: BVB

Method: ML ARCH - Normal distribution (BFGS / Marquardt steps)

Date: $09 / 04 / 20$ Time: 11:55

Sample: 1103

Included observations: 103

\begin{tabular}{|c|c|c|c|c|}
\hline Variable & Coefficient & Std. Error & z-Statistic & Prob. \\
\hline @SQRT(GARCH) & -4.315485 & 2.163040 & -1.995101 & 0.0460 \\
\hline GERMANY_DR & -0.000162 & $3.29 \mathrm{E}-05$ & -4.920078 & 0.0000 \\
\hline $\mathrm{C}$ & 8.275891 & 0.572681 & 14.45114 & 0.0000 \\
\hline \multicolumn{5}{|c|}{ Variance Equation } \\
\hline $\mathrm{C}$ & 0.000367 & 0.000907 & 0.404698 & 0.6857 \\
\hline $\operatorname{RESID}(-1)^{\wedge} 2$ & -0.049436 & 0.046363 & -1.066271 & 0.2863 \\
\hline $\operatorname{RESID}(-1)^{\wedge} 2^{*}(\operatorname{RESID}(-1)<0)$ & 0.557043 & 0.164332 & 3.389739 & 0.0007 \\
\hline GARCH(-1) & 0.862731 & 0.060031 & 14.37144 & 0.0000 \\
\hline R-squared & -5.714408 & Mean dependent var & & 6.095427 \\
\hline Adjusted R-squared & -5.848696 & S.D. dependent var & & 0.629931 \\
\hline S.E. of regression & 1.648531 & Akaike info criterion & & 0.068986 \\
\hline Sum squared resid & 271.7654 & Schwarz criterion & & 0.248045 \\
\hline Log likelihood & 3.447226 & Hannan-Quinn criter. & & 0.141511 \\
\hline Durbin-Watson stat & 1.000642 & & & \\
\hline
\end{tabular}

From the estimation results above for F.C. Borussia Dortmund's stock during this pandemic, it shows the coefficient of the TARCH parameter $\left(\operatorname{RESID}(-1)^{\wedge} 2 *(\operatorname{RESID}(-1)<0)\right)$ is 0.557043 and significant $(\mathrm{p}$ value $=0.0007$ ) which means that the market did respond more to bad News (the emergence of a pandemic followed by an increase in the number of deaths in Germany), so that directly affects the level of Volatility of F.C. stock returns. Borussia Dortmund. 


\section{Juventus Result}

Table 4. Estimated Tgarch for F.C. Juventus Shares During the Covid-19 Pandemic March-August 2020 Period

Dependent Variable: JUVE

Method: ML ARCH - Generalized error distribution (GED) (BFGS / Marquardt steps)

Date: 09/04/20 Time: 11:46

Sample: 1103

Included observations: 103

\begin{tabular}{lrrrr}
\hline \multicolumn{1}{c}{ Variable } & Coefficient & Std. Error & z-Statistic & Prob. \\
\hline \hline @SQRT(GARCH) & 4.718135 & 0.899336 & 5.246240 & 0.0000 \\
ITALY_DR & $1.16 \mathrm{E}-05$ & $7.82 \mathrm{E}-07$ & 14.85985 & 0.0000 \\
C & 0.426180 & 0.036491 & 11.67894 & 0.0000 \\
\hline \hline C & Variance Equation & & \\
RESID(-1)^2 & 0.000168 & $4.89 \mathrm{E}-05$ & 3.441271 & 0.0006 \\
GARCH(-1) & 0.382611 & 0.139349 & 2.745700 & 0.0060 \\
\hline \hline RESID(-1)^2*(RESID(-1)<0) & -0.467720 & 0.149891 & -3.120399 & 0.0018 \\
R-squared & 0.684365 & 0.060537 & 11.30487 & 0.0000 \\
Adjusted R-squared & 0.892710 & Mean dependent var & & 0.881152 \\
S.E. of regression & 0.890564 & S.D. dependent var & & 0.109128 \\
Sum squared resid & 0.036101 & Akaike info criterion & & -3.945907 \\
Log likelihood & 0.130326 & Schwarz criterion & & -3.766848 \\
Durbin-Watson stat & 210.2142 & Hannan-Quinn criter. & & -3.873382 \\
\hline \hline
\end{tabular}

Source: Author Computation (2020)

From the estimation results above for Juventus F.C. stock during this pandemic, it shows the coefficient of the TARCH parameter (RESID $(-1)^{\wedge} 2 *(\operatorname{RESID}(-1)<0)$ ) is -0.467720 and significant (pvalue $=0.0018)$, which means that the market has indeed responded more to bad News (the emergence of a pandemic followed by an increase in the number of deaths in Italy), so it directly affects the level of Volatility of the stock returns of Juventus F.C. 


\section{Manchester United}

Table 5. Estimated Tgarch for F.C. Juventus Shares During the Covid-19 Pandemic March-August 2020 Period

Dependent Variable: MANU

Method: ML ARCH - Normal distribution (BFGS / Marquardt steps)

Date: 09/05/20 Time: 17:52

Sample: 1103

Included observations: 103

\begin{tabular}{|c|c|c|c|c|}
\hline Variable & Coefficient & Std. Error & z-Statistic & Prob. \\
\hline @SQRT(GARCH) & -1.024290 & 0.226087 & -4.530511 & 0.0000 \\
\hline UK_DR & $1.66 \mathrm{E}-05$ & $2.83 \mathrm{E}-06$ & 5.875962 & 0.0000 \\
\hline $\mathrm{C}$ & 16.02003 & 0.163808 & 97.79751 & 0.0000 \\
\hline \multicolumn{5}{|c|}{ Variance Equation } \\
\hline $\mathrm{C}$ & 0.047743 & 0.025380 & 1.881105 & 0.0600 \\
\hline $\operatorname{RESID}(-1)^{\wedge} 2$ & 0.175286 & 0.070805 & 2.475616 & 0.0133 \\
\hline $\operatorname{RESID}(-1)^{\wedge} 2^{*}(\operatorname{RESID}(-1)<0)$ & 0.927953 & 0.287882 & 3.223382 & 0.0013 \\
\hline GARCH(-1) & 0.462481 & 0.090554 & 5.107230 & 0.0000 \\
\hline R-squared & -0.007613 & Mean dependent var & & 15.62311 \\
\hline Adjusted R-squared & -0.027765 & S.D. dependent var & & 1.092894 \\
\hline S.E. of regression & 1.107963 & Akaike info criterion & & 2.408252 \\
\hline Sum squared resid & 122.7581 & Schwarz criterion & & 2.587312 \\
\hline Log likelihood & -117.0250 & Hannan-Quinn criter. & & 2.480778 \\
\hline Durbin-Watson stat & 0.369761 & & & \\
\hline
\end{tabular}

Source: Author's Computation (2020)

From the estimation results above for Manchester United F.C. shares during this pandemic, it shows the coefficient of the TARCH parameter (RESID $\left.(-1)^{\wedge} 2 *(\operatorname{RESID}(-1)<0)\right)$ is 0.927953 and significant $(\mathrm{p}$ 738 
value $=0.0013$ ) which means that the market did respond more to bad News (the emergence of a pandemic followed by an increase in the number of deaths in Italy), thus directly affecting the Volatility of Manchester United's stock returns.

\section{Discussion}

Ajax Amsterdam, Borrusia Dortmund, Juventus, and Manchester United are big European football clubs that have made an IPO (Initial Public Offering) or stock offering to the public to have a very volatile market tendency. This Volatility is increasingly fluctuating in 2020 when the world is experiencing a pandemic condition caused by the Covid-19 virus. This extraordinary event that failed to predict by all economists can be considered an implementation of the Black Swan theory in the financial industry.

This pandemic condition also directly affects activities involving a lot of the public, one of which is football as a prevalent sport in Europe, where the respective leagues with UEFA's approval are forced to stop and postpone competitions prevent the spread of a more virus massive. The first to stop the league was the Italian Serie A on March 10 because Italy became the European country most affected by the effects of Covid-19. This policy was also followed by the German Bundesliga and English Premier League on March 13, and finally the Dutch Eredivisie on March 13. In Germany, the Bundesliga was officially terminated on March 13, 2020, and finally, the Dutch Eredivisie on April 25, 2020. 
From the estimation results using the TGARCH model, the shares of the 4 football clubs were observed (Ajax Amsterdam, Borussia Dortmund, Manchester United, and Juventus) have a strong response bad News, in this case, the increasing number of positive cases of coronavirus in their countries. This can be seen in the conditional variance chart on the 4 types of stocks studied, as follows:

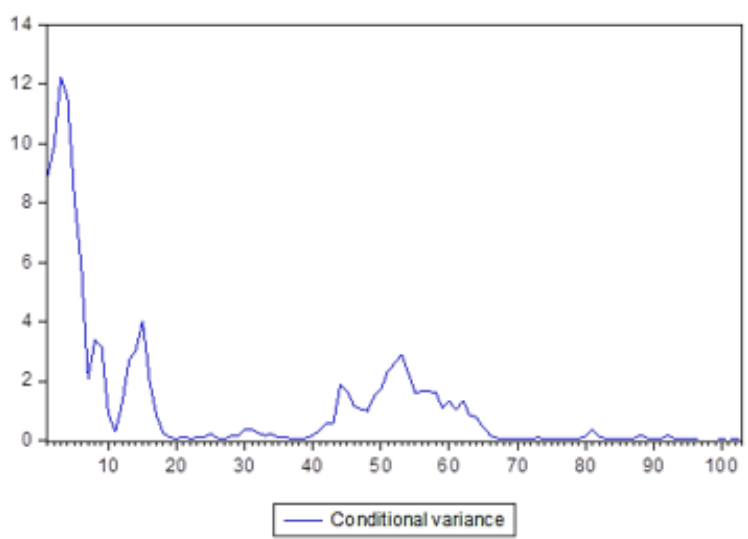

(1) Ajax Amsterdam

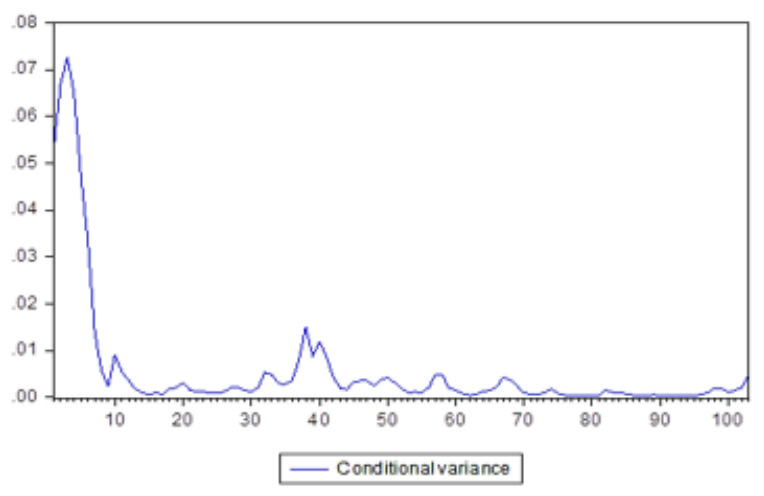

(3) Juventus F.C.

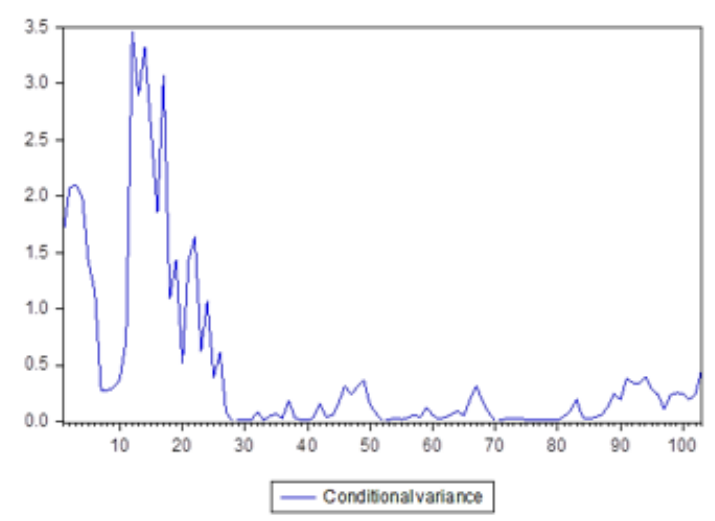

(2) Borussia Dortmund

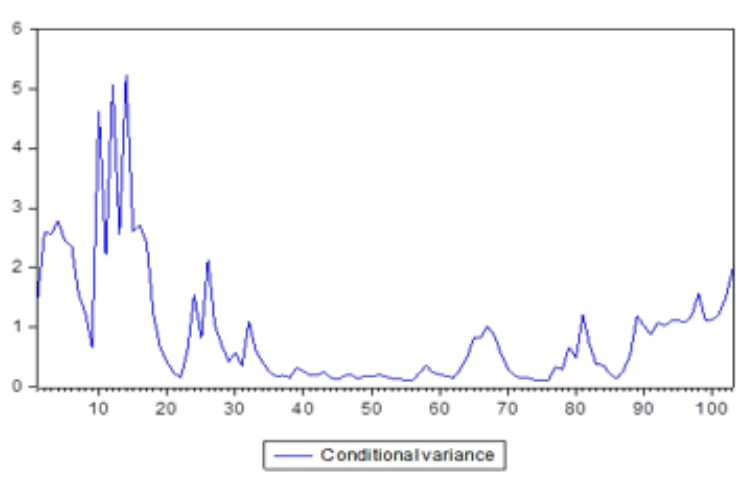

(4) F.C. Manchester United

Figure 2. Conditional Variance

Source: Authors Computation (2020)

From the graph above, it can be seen that in general, the 4 types of stocks that are the focus of the study show similarities, namely experiencing a large swing or high Volatility were the start of the initial period of the Covid-19 pandemic in Europe, which forced the termination of football matches which then further impacted the stock value These football clubs on the stock market.

However, in the next period, it can be seen that there has been a decrease in the level of Volatility, especially entering the middle of 2020, when the implementation of protocols that allow football matches to be held so that it has a direct impact on the condition of the shares of these clubs in the stock market.

\section{CONCLUSION}

The stock market as a short-term investment instrument has very volatile characteristics towards any shock in the economy. The condition of the Covid-19 pandemic has made the economic shock or shock 
even more significant so that the Covid-19 pandemic can be categorized as a black swan effect that affects the financial market due to a negative response to bad News that appears. The Black Swan Effect can be seen more specifically in response to the negative response of stocks of several football clubs that have IPOs in major European stock markets. Furthermore, Ajax Amsterdam (Netherlands), Borussia Dortmund (Germany), Juventus F.C. (Italy), and Manchester United (England) showed negative responses to bad News (covid-19), which was shown through the large swing in the value of club shares. The club during the Covid19 pandemic.

\section{REFERENCE}

Alas, R., Übius, U., Lorents, P., \& Matsak, E. (2017). Corporate Social Responsibility In European And Asian Countries. Jurnal Manajemen Bisnis Dan Inovasi (JMBI) UNSRAT Vol. 4 No. 1

Ariefianto, M.D. (2012). Ekonometrika Esensi Dan Aplikasi Dengan Menggunakan EViews. 1st Ed. Jakarta: Erlangga.

Bollerslev, T. (1986). "Generalized Autoregressive Conditional Heteroskedasticity." Journal of Econometrics.

Deloitte U.K. (2020). Deloitte Football Money League. Manchester.

Engle, R.F. (1982). Autoregressive Conditional Heteroscedasticity with Estimates of the Variance of United Kingdom Inflation." Econometrica.

Gunardi, A. (2014). The Implementation of UEFA Financial Fair Play: An Analysis of Financial Performance of Manchester United. International Journal of Science and Research.

Habib, Z. and Khan, M.,A. (2012). Dividend Policy and Share Price Volatility: Evidence from Pakistan. Global Journal of Management

Hartono, J. (2010). Teori Portofolio Dan Analisis Investasi (Edisi Sepuluh). Yogyakarta: BPFE

Haryoprasetyo, R., and Kiswara, E. (2013). Analisis Atas Kinerja Finansial Klub Sepakbola Profesional : Studi Kasus Pada Manchester United. Diponegoro Journal Of Accounting 2(3): 1-8.

Herdyastoro, KK.M, and Frensidy, B. (2014). Analisis Laporan Keuangan Dan Harga Saham Klub Sepakbola Manchester United, Juventus, Dan Borussia Dortmund. Jakarta.

Hussainey, K, Mgbame, C.O., and Chijoke-Mgbame, A.M. (2011). Dividend Policy and Share Price Volatility: U.K. Evidence. Journal of Risk Finance.

Morales, L. and Andreosso-O'Callaghan, B. (2020). Covid19: Global Stock Markets' Black Swan. Critical Letters in Economics \& Finance 1(1). 
Onali, E. (2020). COVID-19 and Stock Market Volatility. SSRN Electronic Journal.

Rijoly, J.C.D. (2015). Analisis Tingkat Volatilitas Return Saham Pada Perusahan Telekomunikasi Di Indonesia (Study Kasus Pt. Telkom Dan Pt. Indosat). In Peningkatan Daya Saing Dalam Menghadapi ASEAN ECONOMIC COMMUNITY (AEC) 2015, Bandung, ID: Himpunan Mahasiswa Pascasarjana FEB UNPAD.

Sabiruzzaman, Md., Monimul, Md., Beg, R.A., and Anwar, S. (2010). Modeling and Forecasting Trading Volume Index: GARCH versus TGARCH Approach. Quarterly Review of Economics and Finance.

Spiteri, G. (2020). First Cases of Coronavirus Disease 2019 (COVID-19) in the WHO European Region, Eurosurveillance.

Sukati, M.A. (2013). Measuring Maize Price Volatility in Swaziland Using ARCH/GARCH Approach. Munic Personal REPEC Archive.

Taleb, N.N (2007). The Review of Austrian Economics The Black Swan: The Impact of the Highly Improbable. Random House, 2007.

Tulung, J. E., \& Ramdani, D. (2018). Independence, size and performance of the board: An emerging market research. Corporate Ownership \& Control, 15(2-1), 201-208.

UEFA. (2018). UEFA Club Licensing and Financial Fair Play Regulations." Union of European Football Associations.

Zakoian, J.M. (1994). Threshold Heteroskedastic Models. Journal of Economic Dynamics and Control. 